\title{
From spontaneous cyber-solidarities to radicalization of protest speech
}

DOI: http://doi.org/10.26758/8.1.26

Gabriel Stoiciu

'Francisc I. Rainer' Anthropology Institute of the Romanian Academy, Bucharest, Romania,

Address correspondence to: Gabriel Stoiciu, Socio-Cultural Department, 'Francisc I. Rainer' Anthropology Institute of the Romanian Academy, Academy House, 13 September Avenue, No.13, 5th District, Bucharest, Romania, Zip Code 050711, tel. +40728824852; fax +4021.3175072; Email: gabriel.stoiciu@gmail.com

"Once upon a time there were mass media, and they were wicked" Umberto Eco, Travels in Hyperreality

\begin{abstract}
Objectives. Our main goal is to show how important is the role of social media in spontaneous solidarities and the way in which an extreme speech regarding the role and place of religion and state as allegedly responsible institutions for such tragedies can emerge in this environment.

Material and methods. An assessment has been carried out on different social network platforms, among which we chose to present Facebook examples, regarding the attitudes of concerned citizens towards three tragic events that occurred in 2015 in France and Romania. It is also shown the responses of the authorities' to the social media echo of these events.

Results. Even if not widespread, radical attitudes emerge in times of crisis and can leave a trace on future dominant social behavior.

Conclusions. Unfortunately, the most powerful impact in social media, as in the mainstream one, is caused by the "terrible news". The emotional complex surrounding this kind of events varies from despair to anger and sometimes develops into extreme speech.
\end{abstract}

Keywords: Social Media, Tragic Events, Radicalization, Virtual Communities

\section{New media - "Mirror, mirror" or "Jeannie in the lamp"}

Social media - computer platforms for communication and socialization - are becoming more and more "the weapon of choice" used by public opinion to convey their messages, while the mainstream press is often perceived as manipulative and submitted to the interests of the establishment. Platforms like Facebook and Twitter are considered to be more reliable sources of information (a proof is also the number of users over 2.5 billion - higher than any print or TV audience) because censorship seems to be, in this case, less efficient. Newspapers, radio stations, and private televisions are integrated into large business conglomerates and, consequently, they seem only to create an impression of sympathetic interfaces of large unscrupulous companies.

Mainstream media has an institutional form: an organization whose object of activity is to generate cultural products (articles, reports, radio-TV programs) addressed to an audience of individuals who are in a passive posture - that of recipients who are unable to provide an instant reply to the information and opinions that are communicated to them. 
"Media are forces that provide the public with ways to perceive and interpret the world, ways that ultimately structure its very existence and participation in a given society" (Spitulnik, 1993, p.294).

The web 2.0, whether we are talking about forums, blogs or social networking platforms, make it possible for the perception of an event to be changed directly and spontaneously by those who are addressing it. This is happening independently of the filter of professional public opinion analysts/commentators. At the same time, new information and communication technologies leave the impression that they can offer "instant gratification" to the user and provide the opportunity for someone to become famous overnight. This is the essence of what we call web 2.0 - the era in which the Internet is no longer composed, like the press, of pre-fabricated content (as it was in the beginning) but is constantly under the influence of the ideas and opinions that are associated with the initial message - its essence being the creation and animation of „virtual communities”. Using the computer as the primary means of communication has led to the formation of a "public sphere" within the virtual space - a virtual or "imagined community - that does not necessarily exist in an identifiable space." (Habermas, 1962) Such groups are often formed around the need to communicate and socialize, but also as a "community of interest" - in which members "exchange information in order to get answers to questions or personal problems, in order to and improve understanding of a subject, to share common passions or simply to play" (Henri and Pudelko, 2003, p.485). However, there are situations where such communities develop spontaneously - in response to an event of great interest.

Public events with a tragic connotation, reflected by the mass media, can induce two behavioral rearing at the receptor level: indifference or empathy. The latter can be expressed both publicly and privately through an affective complex ranging from despair to anger. Anger involves an intention, a willingness to act, and an orientation (a target). Most often, the target of anger reactions are the authors of the tragedy, but also the authorities, a fragment of society or a system of values considered wrong (religion, democracy, etc.).

On the channels of the new media, the tragic news come instantly - accompanied almost simultaneously by the public's reactions. This kind of events creates spontaneous cyber-solidarities generating - what Robert Putnam called - ,social capital”.

The main objective of this material is to highlight, through the comparative method, the role that socialization platforms play in the formation of spontaneous solidarities and the way in which radical opinions and attitudes directed against secular or religious authorities arise in such situations. At the same time, we will also analyze the authorities' response to these attitudes.

\section{Collective emotions in the face of social tragedies}

Unfortunately, for both conventional media and social networking platforms, the so-called "terrible news" gets the strongest impact. The emotional complexity that accompanies this type of events varies from despair to anger and sometimes develops even in radical attitudes.

The year 2015 brought a maximum exposure to terrorist attacks claimed in the name of Islamic fundamentalism committed in France ("Charlie Hebdo" and "Bataclan"). These events offered the possibility for extreme right activists to challenge the legitimacy and authority of political leaders in office. 


\section{Attack against Charlie Hebdo}

Charlie Hebdo is a weekly French magazine of political and social satire, which has often created controversy because of its provocative style, often caricaturing the founding characters of religions (Jesus, Mahomed, Moses). Due to the caricatures of the Prophet Muhammad, journalists received many threats, and the first headquarters of the magazine had been fire-bombed in 2011.

Parisian prosecutors confirmed that on the morning of January 7, 2015, two masked and armed attackers stormed editorial offices located in Paris and began firing automatic weapons. 12 people were killed (10 journalists and 2 policemen) and 11 were injured in the attack on the satirical weekly. The authors of the attack were identified as Saïd Kouachi and Chérif Kouachi, aged 34 and 32 respectively. They were shot, during an ambush, two days after the attack.

The popular reaction was immediate, although the publication did not have a very large audience. Information disseminated on social media platforms, especially on Facebook and Twitter, has generated solidarity under the slogan "Je suis Charlie" (Image 1, promoted also as a hashtag) around the principles underlying the independence of the press and freedom of expression.

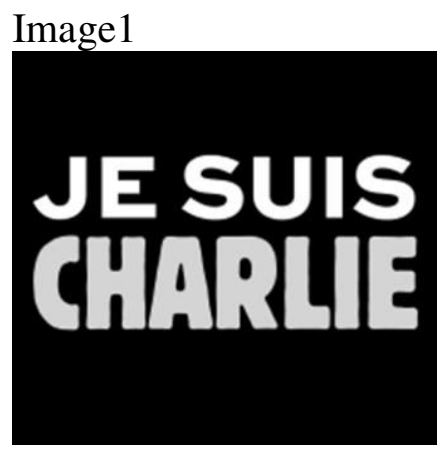

This solidarity also emerged in the streets, through massive protest movements that took place in the evening of the bombing and in the coming days in many cities in France and around the world. The slogan "Je suis Charlie" would be adapted later on by replacing the name of the publication with that of the cities where attacks were claimed in the name of Islamic fundamentalism (Je suis Orlando, Je suis Brussels, Je suis Istanbul, etc.). Besides the reactions of peaceful solidarity around democratic values, there have been also violent reactions both in language (injuries, threats, and instigations spread on social networking platforms) and in action (burning and vandalizing mosques, shuffling people, including children of Muslim religion). The President of France and the majority of the political class have taken the initiative to organize a protest march involving 1 million people. French heads of state were joined by other EU heads of state and leaders.

\section{The terrorist attacks in Paris on 13 November 2015}

They were series of armed attacks, bombings, and hostage-taking, which took place in the capital city of France on the evening of 13 November 2015 and in the early hours of the following day in the 10th and 11th arrondissements and near Stade de France, located in Saint-Denis. The attacks, which were claimed by the Islamic State (ISIL) group, consisted of three explosions and six armed attacks. The day was chosen because there was a football match between France and Germany, which attracted the participation of many French on the stadium, but also in gatherings in Paris cafes. Explosions by self-detonation took place near Stade de France, and the shootings (more 
randomly drawn) targeted the cafes. But the bloodiest attack happened in the Bataclan Theater, where a rock concert took place. More than 100 persons were arrested and killed in Bataclan, and the terrorists eventually committed suicide. In total, the November 2015 attacks resulted in 130 people killed and 368 injured.

The Parisians responded to these abominable acts through immense solidarity. The hashtag \#portesouvertes was launched on the social networking platforms for those who were in the city and were afraid to travel to their hometown. There were also, Facebook users have adopted logos with French tricolor and the mention "Je suis Paris". Online pages were opened in which those known to be in the areas concerned by the attacks would leave a "proof of life" to calm their friends and relatives. Also, spontaneous displays of feelings of resentment in the face of terrorism and compassion towards those close to the victims animated the big cities in France. President François Hollande declared a state of emergency for a period of three months and again called for solidarity. This time, however, public opinion, especially on online networks, has adopted a critical orientation towards political leaders and especially the head of state.

\section{Fire at Collective Club}

Also, in 2015, Romania had its part of "terrible news" with the fire that burned down the "Collective" night-club in Bucharest, killing 64 people and injuring 147. The official reports, mentioned by daily newspaper Romania Liberă, certified as a cause of fires: a tragic association between the fact that "the fireworks that were mounted in the Collective club (especially for the concert $n n$ ) were not correctly positioned", and "the fact that there were no extinguishers in the club." To them, it was added "the non-fireproofing of the polyurethane foam (mounted on the walls of the silent $n n$ ) which rapidly ignited". There have been and still are opinions that invoke the possibility of other causes, reaching up to different conspiration theories.

The fact that this metal-core concert took place on Halloween night fueled radical positions of Christian-Orthodox self-declared observers, expressed on social networking platforms. These have attracted equally vehemently secular replies, not directed to the contributors, but to clergy and Orthodox religion. The message "We want hospitals, not cathedrals" (Image 2) has become a slogan strongly promoted by online social media platforms. Through the same channels, the call for a march, two days after the tragedy was launched on November 1. The march took the form of a protest against the incompetence and perfidy of central and local government officials (specifically, the Mayor of $4^{\text {th }}$ District of Bucharest - where Collective club was situated). The participants' resentment expressions found an essentialization in the slogan "Corruption kills", which later became the name of a Facebook page followed by many of those who blamed the authorities for the Collective tragedy and which served as the main channel for mobilizing resistance to abuse committed by the State. The authorities let the impression that they are insensitive to people's inquiring and launched the information that the number of victims diminished in order to control the public's reaction. This fact has quickly come to the surface, a new march was organized on November 3rd, an occasion where explicitly was requested the resignation of Prime Minister Victor Ponta (and thus the Government) and of the Mayor of $4^{\text {th }}$ district, Cristian Popescu-Piedone. These gestures of the two politicians came the next day. 
Image 2

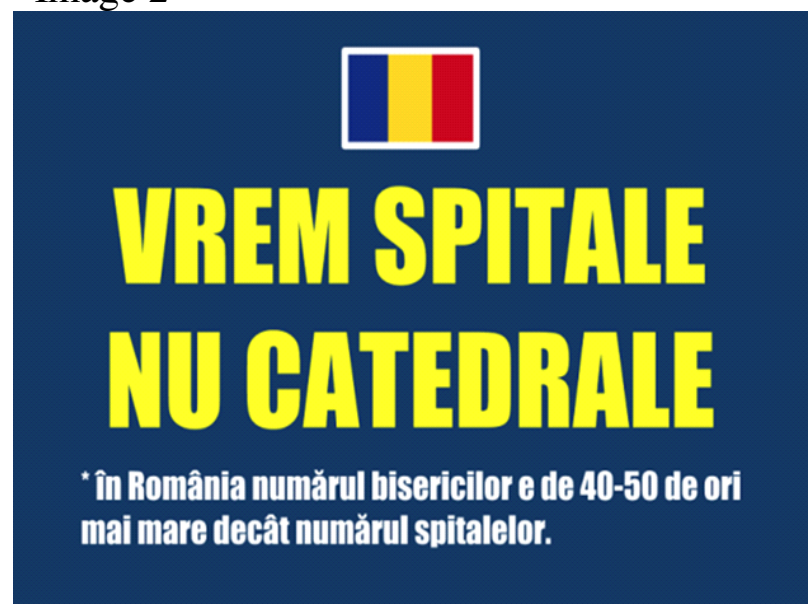

\section{Hacktivism and E-democracy in the context of tragic social events}

Virtual communities often demonstrate civic engagement through initiatives that address issues of public interest. Xenos and Moy (2007, p.708) show that the Internet does help civic engagement but also give "unjustifiable euphoria, abrupt and equally unjustifiable skepticism, and gradual realization that web-based human interaction really does have unique and politically significant properties." Activism that uses Internet resources can take on multiple forms of expression: online petitions, hacking (eg "leakage" of confidential information - Wikileaks or Anonymus), calls to mobilize to public protests or riots, etc. All of these actions fit into the conceptual universe of E-democracy, which implies the use of virtual space to create economic, social and cultural conditions to support the promotion of individual freedoms. These premises underpinned the emergence of major international social movements (Occupy, Indignados, Arab Spring) and mobilization at country level like: Salvaţi Roşia Montana (Save Roşia Montana), Corupţia Ucide (Corruption Kills) in Romania.

The most widespread form of E-democracy manifestation is to address online platforms. Both in the case of the terrorist attacks in France and the fire at the Collective Club, the official pages of some institutions, but also the Facebook and Twitter platforms hosted the views expressed by several thousand people. The present paper aims to point out in a comparative perspective some radical attitudes of different individuals confronted with the above-mentioned events expressed on Facebook. Here are some examples of resentment attitudes (more varied in form and content than the compassionate ones):

a) François Hollande's official Facebook page of the President of the French Republic (https://www.facebook.com/francoishollande.fr/?fref=nf):

Maël Guinot: „Arrête de dire qu'on vainc les terroristes ... on ne fait qu'encaisser les coups sans rien faire ! ... Ce n'est pas en marchant dans la rue que tout cela va s'arranger" (Stop saying we will overcome the terrorists ... we only take blows without doing anything! ... Not by marching in the streets all this will be solved)

Like • 5,098 • November 14, 2015 at 01:25

Alexander Gharib: "François Hollande demande la fermeture des Frontières afin d'éviter aux terroristes de venir sur le territoire français. Tout le monde critiquait Marine Le Pen qui l'a toujours 
demandé. Bravo Hollande d'avoir attendu 120 morts pour cela !!!!!!!!!!” (F. Hollande calls for the closure of the frontiers today to avoid the intrusion of terrorists into French territory. Everyone criticizes M. le Pen who has always demanded that. Bravo Hollande, it took 120 dead for you to do this !!!)

Like $\bullet 460 \bullet$ November 14, 2015 at 04:18

b) Facebook page for the Bataclan Paris attack (https://www.facebook.com/Je-suis-paris$\underline{1663517807228311 /)}$

David Lucas: "Au vue de votre incompétence évidente, vous devez démissionner dans l'urgence ainsi que tout le gouvernement de corrompus qui vous accompagne!!! Vous êtes un traître envers la France et les français !!!!!" (Due to your obvious incompetence, you should resign urgently along with the corrupt government that accompanies you!!! You are a traitor of France and the French!!!!)

Like $\cdot 77 \cdot$ November 14, 2015 at 20:25

Clo Lacour: “ C'est bizarre mais nous n'avons en France aucun problème avec d'autres religions, la seule avec qui les problèmes s'accumulent, devinez, "l'Islam". J'ai 70 ans je ne le verrai pas mais je plains mes enfants, la troisième guerre mondiale viendra de ces barbares qui tuent, qui violent..." (It's strange, but we do not have any problem with other religions in France, the only one where problems pile up, guess which: the Islam. I'm 70 years old, I will not grab, but I'm crying my children, the third world war will come from these barbarians, who kill, who violates...) Like $37 \cdot$ November 15,2015 at 12:27

c) Bucharest: October 30, $2015-$ Colectiv Club - Facebook page (https://www.facebook.com/pg/ajutorcolectiv/posts/?ref=page_internal)

Corina Maria Unga: "Daca ar fura mai puţin (cei din guvern) şi s-ar gândii [sic!] şi la noi oamenii de rând, am putea fii [sic!] o ţară exemplară, cu locuri de muncă bine plătite.. cu spitale amenajate corespunzător.. cu străzi fără gropi.. etc.. şi noi am putea trăi acasă lângă copii [sic!] nostri.. nu la mii de km depărtare" (If they would steal less (the government) and would think of us ordinary people, we could be an exemplary country with well-paid jobs ... with proper hospitals .. with streets without pits. etc. ... and we could live at home beside our children ... not thousands of miles away) Like $13 \cdot$ November 1,2015 at 6:40 pm

Mihai Cristea: "Din cauza voastră s-a întâmplat tot carnagiul asta, voi sunteţi de vină vă este frică de generaţia noastră credeţi că noi dormim dar o să vină şi ziua în care o să plătiţi voi cu vârf şi îndesat pentru tot ceea ce a-ti [sic!] făcut în Ţara asta jeguri nesimţite." (Because of you all this carnage happened, you are to blame, you are afraid of our generation you think we are sleeping but it will come the day you will pay in full for everything you did in this country, you insensitive scam.) Like 72 - November 2, 2015 at 20:56

Frenk Soja: "Acum chiar ne-au ajutat cele 18.000 de biserici care [sic!] le avem în ţară". (On this occasion, the 18,000 churches that we have in the country "really" helped.)

Like $45 \cdot$ October 31, 2015 at 15:15 
Gabriela Serban: "acum 25 de ani nu se știa de sărbatoarea halloween! ...este o sarbătoare ...satanistă "(25 years ago, nobody knew about Halloween! ... it is a satanic celebration ...) Like $85 \cdot$ November 1, 2015 at 01:23

Mereuta Gicu Jimmy: “ Politicienii bagă bani în biserici, nu în spitale. Şi în cazuri din astea, se cere ajutorul populaţiei pt donaţii... să dea D-zeu un incendiu de 10 ori mai mare, în camera Parlamentului...să ardeti toţi de vii, politicieni corupţi ce sunteţi!!!” (Politicians are spending money for churches, not hospitals. And in these cases, donations are needed from the population ... let God bring a 10 times bigger fire in the Chamber of Parliament ... let all you corrupt politicians burn alive!!!)

Like $41 \cdot$ November 2, 2015 at 08:32

The common trait of all these attitudes is the fact that they address real problems in an uninhibited manner, to say the least. And even they were not the dominant trend and did not generate large-scale public unrest, this kind of radical speech had its echo on collective conscience. President F. Hollande became the most unpopular president ever and gave up the pursuit of a second term. Marine Le Pen the candidate of far-right party, Front National, reached the second tour of presidential elections. Victor Ponta, Romania's prime minister in 2015 resigned and became an unimportant actor in the political landscape.

\section{Conclusions}

Regardless of what geographic and cultural space would come from, people's reactions to such deep tragedies reach an equivalent level of intensity. Beyond the opportunity to express ideas, criticisms, or even bad language to the shelter of anonymity, the online environment also creates the possibility of crystallizing collective attitudes in support of causes or principles that cross geographical or political delimitations. Cyber-activism is not protected from attempts to manipulate or hijacking (trolling), but unlike the mainstream media, the lack of opinion leaders or spokespersons makes these actions less effective. Also, the lack of censorship or a 'code of ethics' allows the information to reach the individual in its raw state, which is why the quantity and intensity of the first emotions are considerably higher than when receiving information from the press.

Virtual communities are "goal-oriented, created to carry-out a specific mandate" which rely on ,sharing of diverse perspectives and objects commissioned by the mandate" and on "knowledge construction from diverse knowledge systems towards collective use" (Henri and Pudelko, 2003). National and international authorities cannot ignore these new forms of expression of solidarity, either spontaneous or built over time. Beside sporadic extremist accents, collective attitude is essentially manifested through actions meant to defend universal principles and values on which modern civilization is founded.

\section{References}

1. Anderson, B., 1991. Imagined communities: reflections on the origin and spread of nationalism. London: Verso. 
2. Habermas, J., 1989. (1962) The Structural Transformation of the Public Sphere. Cambridge: Polity.

3. Henri, F., Pudelko, B., 2003. Understanding and analysing activity and learning in virtual communities. Journal of Computer Assisted Learning, 19, pp.474-487.

4. Melucci, A., 1995. The Process of Collective Identity. In: H. Johnston and B. Klandermans, eds. Social Movements and Culture. Minneapolis: University of Minnesota Press. pp.41-63.

5. Mitrovici, E., 2016. Raport final în tragedia din Colectiv: Flăcările s-au propagat mai repede decât se crede. România Liberă (daily newspaper) (online version) Available at: http://romanialibera.ro/actualitate/eveniment/flacarile-s-au-propagat-mai-repede-decat-secredea--se-spune-in-raportul-final-in-ancheta-colectiv-412137 [Accessed 22 January 2018]

6. Putnam, R., 2000. Bowling Alone: Collapse and Revival of American Community. New York: Simon \& Schuster.

7. Rheingold, H., 1993. The Virtual Communities: Homsteading on the Electronic Frontier. Reding, Massachusets: Addison-Wesley.

8. Spitulnik, D., 1993. Anthropology and Mass Media. Annual Review of Anthropology, 22, pp.293-315.

9. Xenos, M., and Moy, P., 2007. Direct and differential effects of the Internet on political and civic engagement. Journal of Communication, 57(4), pp.704-718. 